\title{
History of environmental impact assesment in Indonesia
}

\author{
F. S. Dhiksawann ${ }^{1,2}$, S. P. Hadi ${ }^{3}$, A. Samekto 4 , D. P. Sasongko ${ }^{5}$ \\ 1Doctorate Programme of Environmental Science, Diponegoro University, Semarang, Indonesia \\ ${ }^{2}$ Geography Programme Studies, Faculty of Trainning Teacher Cenderawasih University, Papua, Indonesia \\ ${ }^{3}$ School of Postgraduate Studies, Diponegoro University, Semarang, Indonesia \\ ${ }^{4}$ School of Postgraduate Studies, Diponegoro University Semarang, Indonesia \\ ${ }^{5}$ Faculty of Sciences and Mathematics, Diponegoro University, Semarang, Indonesia
}

\begin{abstract}
Abstrak.
Penelitian tentang sejarah analisis mengenai dampak lingkungan (amdal) di Indonesia bertujuan untuk memperoleh gambaran perubahan regulasi amdal. Metode dan materi penelitian ini berupa studi pustaka jurnaljurnal, buku-buku teks dan dukumen-dokumen penelitian tentang sejarah amdal. Penelitian menghasilkan gambaran sejarah awal mula amdal di Indonesia. Dimulai dari keikutsertaan Pemerintah Republik Indonesia pada Conference on the Human Environment (UNCHE) di Stockholm tahun 1972 dan 1973 Indonesia memulai memasukan pertimbangan lingkungan ke dalam program pembangunan nasional, melalui Ketetapan Majelis Permusyawaratan Rakyat Nomor IV Tahun 1973 dalam Garis-garis Besar Haluan Negara Bab III bagian B butir (10). Undang-undang lingkungan hidup pertama kali di Indonesia dikeluarkan tahun 1982 yang kemudian mengalami pergantian pada tahun 1997 dan 2009. Pasalpasal dalam undang-undang mencatumkan amdal sebagai salah satu instrumen pencegahan kerusakan lingkungan. Peraturan pemerintah tentang amdal pertama kali diimplementasikan melalui Peraturan Pemerintah Nomor 29 Tahun 1986, selanjutnya diganti dengan Peraturan Pemerintah 51 tahun 1993 dan kemudian Peraturan Pemerintah Nomor 51 tahun 1993 dinyatakan tidak berlaku lagi dan diganti dengan Peraturan Pemerintah Nomor 27 tahun 1999. Selama kurun waktu 3 (tiga) tahun diganti dengan Peraturan Pemerintah Nomor 27 Tahun 2012 tentang Izin Lingkungan.
\end{abstract}

Kata kunci: sejarah, amdal, peraturan pemerintah, undangundang

\begin{abstract}
.
This research on the history Environmental Impact Asessment (EIA) in Indonesia is aimed at obtaining an overview of the changes in regulations concerning EIA. It methods and materials in the form of library study including journals, books, and research documents on the history of EIA. The research produced an overview of the early history of EIA in Indonesia. The overview starts from the participation of the Government of the Republic of Indonesia in the Conference on the Human Environment (UNCHE) Stockholm in 1972. In 1973 Indonesia began inserting environmental consideration into the national development program based on the Decree of the People's Consultative Assembly Number IV of 1973 in the Broad Outlines of State Policy Chapter III Part B item (10). Environment law was firstly enacted in Indonesia in 1982. As time went by, the environmental laws went changes in 1997 and 2009. This law mandated the enactment of government regulation concerning EIA. EIA was first implemented in Indonesia based on the Government Regulation Number 29 of 1986. It was replaced with the Government Regulation Number 51 of 1993. Then It was revoked and replaced with Number 27 of 1999. After 3 (three) years replaced with Number 27 of 2012 on environmental license.
\end{abstract}

Keywords: history, environmental impact assessment (eia), government regulation, law

\section{INTRODUCTION}

After the Conference on the Human Environment (UNCHE) in Stockholm in 1972, Indonesia began put environmental consideration into the national development program that in 1973 the Decree of the People's Consultative Assembly Number IV of 1973 in the Broad Outlines of State Policy Chapter III Part B item (10) officially included environmentally sound development.

\footnotetext{
${ }^{*}$ Korespondensi Penulis

Email : dhiksawan@yahoo.co.id
} 
As time went by, the environmental law underwent changes in 1997 and 2009. This law mandated the issuance of the Government Regulation concerning environmental impact assessment as an instrument to prevent environmental damage.

The government regulation concerning environmental impact assessment underwent changes following the changes in the environmental laws, namely the issuance of the Government Regulation Number 29 of 1986, the Government Regulation Number 51 of 1993, the Government Regulation of 27 of 1999 and the Government Regulation Number 27 of 2012 on environmental license. This research is aimed to obtain an overview of the history of environmental impact assessment in Indonesia. Therefore, it is expected that this research can obtain information about the effectiveness and efficiency of the environmental impact assessment process in Indonesia.

\section{RESEARCH METHODS AND MATERIALS}

This research employed library study from various literatures of which materials consisted of international journals, books, and research results on the involvement of the people in the process of environmental impact assessment from 1995 to 2013.

\section{RESEARCH RESULTS}

The environmental impact assessment was first introduced in the United States of America on December 31, 1969 since the enactment of the National Environmental Protection Act (NEPA). This law required projects that had impacts on biophysical environmental components to make an environmental impact assessment (Canter 1996; Hadi 2009).

Canter (1996) states that: "Environmental impact assessment" (EIA) can be defined as the systematic identification and evaluation of the potential impact (effects) of proposed projects, plans, program, or legislative actions relative to the physical-chemical, biological, cultural, and socioeconomic components of the total environment. This definition show that every activity or program planning starts by conducting a systematic identification and evaluation on the potential impact that may occur on the total environment including physical, chemical, biological, cultural and socio economic impacts.

EIA is a process of analyzing and evaluating environmental impacts caused by human activities. EIA is aimed at guaranteeing the achievement of sustainable development, which is creating harmony between human prosperity and ecosystem conservation. Therefore, until now EIA is an effective tool in planning environmental management. EIA is an activity that involves people starting from giving information about the activity plan, identification, and evaluation of 
environmental change as a result of project activity and their involvement in decision making process.

In addition, EIA is a technical key to combining concepts such as the principles of preventing natural resource loss and making right decision to achieve the main objectives of sustainable development (Zamorano 2013).

In Indonesia, Environmental Impact Assessment is defined in Law Number 32 of 2009 on conservation and management of Environment article 1 number (11) stating that environmental impact assessment is an assessment on crucial impacts of a business and/or activity that is planned on the environment which is necessary for a decision making process concerning the implementation of business and/or activity. EIA is also one of the instruments to prevent pollution and/or environmental damage (Law Number 32 of 2009 item 14 (e)).

Based on the articles in this law, there are 2 (two) key words on the definition of environmental impact assessment, namely (1). A study con the important impacts of a business and/or activity plan and; (2) the process of decision-making concerning the implementation of a business and/or activity. A study on the important impacts of a business and/or activity plan has a scientific significance. This is indicated that the process of EIA uses quantitative and qualitative scientific methods, especially in analyzing the possibilities of the impacts that may occur if a plan will be executed. Therefor, EIA as an instrument to prevent pollution and/or environmental damage is an activity of study that is scientifically reliable.

The study process in environmental impact assessment is carried out through the process of making a proposal (making of terms of reference), field research (making of environmental impact assessment) and giving suggestions and recommendations in the form of plans in managing the important impacts of an activity and the monitoring plans (making environmental management and environmental monitoring plans). All process taking place on the making of environmental impact assessment is used as a consideration for the decision of environmental feasibility. This decision making on environmental feasibility will serve as the requirements for the obtaining a license for activities utilizing natural resources.

\subsection{The birth of environmental impact assessment in Indonesia}

As a result from the participation of the Government of the Republic of Indonesia in the Conference on the Human Environment (UNCHE) in Stockholm in 1972, in 1973 the Government of the Republic of Indonesia first included environmentally sound development programs in the Decree of the People's Consultative Assembly.

One of the environmental development programs contained in Decree of the People's Consultative Assembly Number IV of 1973 in the Broad Outlines of 
State Policy Chapter III Part B item (10) stating that: "In the implementation of development, Indonesian natural resources must be used rationally. Natural resources must be exploited in a way which does not damage human environment, is carried out with full wisdom and calculates the needs of future generations".

In 1975 through the Presidential Decree Number 27 of 1975, the Government of the Republic of Indonesia established an inventory and evaluation committee on natural resources. This committee was assigned to make a nationwide analysis on demand and supply pattern as well as present and future technological advances in order to assess social, economic, environmental, and political implication which would serve as the basis for deciding utilization policy and its security as national development resource at that time. The Presidential Decree Number 27 of 1975 was followed up by the Decree of Minister of Research Number 13 of 1975 on the Establishment of Work Program Formulating Committee for Natural Riches and Coordination, Integration, and Synchronization Committee.

Based on the results of the formulating committee, in 1978 the Government of the Republic of Indonesia produced a formula in the Decree of the People's Consultative Assembly Number IV of 1978 concerning the Broad Outlines of State Policy Chapter IV Part D item (19) stating that One of the important aspects in economic development is the utilization of natural and environmental resources.

Accordingly, it is necessary to improve inventory and evaluation of natural and environmental resources. Similarly, it is necessary to improve rehabilitation of damaged natural and environmental resources and steps to prevent damage on natural and environmental resources in order to ensure their sustainability". Based on the Presidential Decree Number 35 of 1978, in 1978 as a follow up to the Broad Outlines of State Policy, for the first time the Government of the Republic of Indonesia appointed a minister that coordinated government apparatuses assigned to supervise development and environment as well as to improve environmental management.

In 1980, the Presidential Decree Number 27 of 1975 was replaced by the Presidential Decree Number 68 of 1980 on the establishment of the committee of natural resources inventory and evaluation. This decree was aimed at further improving the implementation of the committee of natural resources inventory and evaluation as well as establishing the position of the principal tasks and functions in order to support the implementation of national development by appointing the Minister of Development and Environment Supervision as vice chairman of the committee.

Two years later, in 1982, the government proposed a draft of environmental law, which was then legalized by the House of Representative in 
March 1982. Law Number 4 of 1982 was enacted in March 11, 1982. This law contained the principal provisions of environmental management. One of considerations for the enactment of this law was that environment was a gift from the almighty God, so that utilizing natural resources should consider sustainable and environmentally sound development by calculating the needs of current and future generations. Article (1) item (10) of this law starts the explanation about environmental impact assessment. The environmental impact assessment is a study on the impact of an activity that is planned on the environment, and is needed for a decision making process. Article (16) states that every plan estimated to have a crucial impact on the environment must be complemented with an environmental impact assessment of which implementation is regulated in the government regulation.

In 1987, the World Commission on Environment and Development (WCED) through the Brundtland Commission first proposed the concept of sustainable development project. Then in 1992, the Indonesian government participated in the Conference on Environment and Development (UNCED) or Earth Summit in Rio de Janeiro, Brazil. In this conference, sustainable development program was proposed to be extended and continued to be applied in every development program (Death 2014). Since then, the Government of the Republic of Indonesia started to make various adjustments on all development policies. Environmentally sound development was poured into the environmental law of the Republic of Indonesia Number 23 of 1997.

Various environmentally sound developments were continuously adjusted by the government. Such changes are not only resulted from political situation in the country (Old Order before 1966, New Order 1966-1998, Reform Order 1998present), but also pressures from the world that the Government of the Republic of Indonesia should implement the environmentally sound and sustainable development.

Political change in the country brings consequences to the changes in the environmental law and the government law that follows. Environmental laws changed 3 (three) times within 27 years from 1982 until 2009. Law Number 4 of 1982 concerning Basic Provisions of Environmental Management was officially replaced with Law Number 23 of 1997 on Environmental Management in September 19, 1997, and Law Number 23 of 1997 was revoked as of October 3, 2009 and replaced with Law Number 32 of 2009 on Environmental Conservation and Management. The government regulation on environmental impact analysis also underwent changes following the changes in the Environmental Law.

Environmental impact assessment (EIA) was first implemented in Indonesia in 1986 through the enactment of the Government Regulation Number 29 of 1986 on environmental impact assessment as mandated by Environmental Law Number 4 of 1982. The Government Regulation concerning 
environmental impact assessment (EIA) has had changed 3 (three) times within 25 years from 1986 to 2012. First, Government Regulation Number 29 of 1986 on environmental impact assessment was replaced with Government Regulation Number 51 of 1993 on environmental impact assessment. The latter government regulation concerning environmental impact assessment still referred to Law Number 4 of 1982 and due to practical reason in a decision making process. Second, the change occurred because Law Number 4 of 1982 was revoked and replaced with Law Number 23 of 1997. Therefore, Government Regulation Number 51 of 1993 on environmental impact assessment was revoked and replaced wit Government Regulation Number 27 of 1999 on environmental impact assessment. In this year, the word lingkungan (environment) was added with hidup (living/life) so it became lingkungan hidup (living environment). Third, because Law Number 23 of 1997 was replaced with Law Number 32 of 2009, on February 23, 2012 Government Regulation Number 27 of 1999 on environmental impact assessment was revoked and replaced with Government Regulation Number 27 of 2012 on Environmental License.

\subsection{Process of making environmental impact assessment in Indonesia}

In general, the making of environmental assessment in Indonesia is aimed at obtaining a decision on environment feasibility for a plan running an activity or business that has significant impact on the environment. Specifically, the making of environmental impact assessment is aimed at, first, obtaining data and information of a business or activity plan; second, obtaining accurate data and information about preliminary environmental setting where the activity and/or business that has significant impacts will take place; third, obtaining the results of an estimation of a massive and significant impacts of an activity plan on the change in environmental components and mitigation efforts towards the significant impacts caused by the business and/or activity plan; fourth obtaining results of evaluation of significant impacts of a business and/or activity plan that can have significant impacts on the change in the quality of environment; fifth, obtaining a management and monitoring planning program for the quality of environment that is estimated to be affected by the significant impact of a business and/or activity plan.

Administratively, the stages of environmental impact assessment (EIA) in Indonesia include screening, making documents of environmental impact assessment, evaluating environmental impact analysis documents, making decision on the environmental feasibility based and the study results and environmental impact assessment of a business and/or activity plan. The process and guidelines for the making of environmental impact assessment in Indonesia developments and changed as the changes in Laws and Government Regulations. 


\subsubsection{Period 1982-1992}

This period used Government Regulation Number 29 of 1986 on environmental impact analysis. Some important things in the environmental impact assessment based on the Government Regulation in this period was as follows:

First, procedures for environmental impact assessment based on government regulation that the project initiator should propose the project to the Minister or Person in charge of relevant activity. The proposal contained whether it was necessary to complete such activity in with environmental information presentation (EIP). The requirements of EIP or early screening were activity changing land and landscape, exploitation of renewable and nonrenewable natural resources, activity causing depletion, damage or deterioration of natural resources, activity affecting social and cultural environment, affecting conservational area and cultural heritage, activity introducing plants, animals, microorganism, making and using biological and non-biological materials, and activity applying technology predicted to have a great potential impact on the environment.

Second, after such activity is declared to have significant impacts by the minister or the person in charge, the activity should be equipped with an environmental impact assessment (EIA). The guideline concerning the extent of significant impacts is determined by the minister in charge of managing the environment.

Third, if the initiator thinks that the plan will have significant impacts on the environment, the initiator and the responsible institution directly make a term of reference for the making of the environmental impact assessment without making the EIP first.

Fourth, it is not necessary to environmental impact assessment for an activity plan that is immediately carried to overcome an emergency circumstance. This decision is made after the minister or the person in charge consult with the minister assigned for managing the environment.

Fifth, if the responsible institution, in this case the minister or the governor, declares that the environmental impact assessment must be made, the initiator must make a term of reference (at the latest 30 days after being decided by the commission).

Sixth, the environmental impact assessment made by the initiator is then submitted to the responsible institution, in this case the minister or governor, to be evaluated by the commission. The evaluation commission decides to approve or reject the environmental impact assessment (at the latest 90 days after being decided by the commission). If the commission rejects, the initiator must revise the proposal and re-submit to the commission to obtain approval for the 
environmental impact assessment (at the latest 30 days after being decided by the commission).

Seventh, if the deadline for deciding the term of reference of environmental impact assessment is passed by the commission, based on the power of this government regulation the activity will obtain an approval.

Eighth, if the result of environmental impact assessment states that that negative impact is greater than positive impact and such impact cannot be overcome by science and technology, the minister or governor can reject such activity plan. Subsequently, the initiator is given 14 days to file an objection to the decision. In such case, the minister or governor is given 30 days to process the initiator's objection (if the deadline is passed, the initiator's objection is considered as accepted based on the power of government regulation, the environmental management plan and environmental monitoring plan can be made).

Ninth, after the permission is granted, the initiator directly submits the environmental management plan and monitoring plan to the minister or governor in this case referred to as the institution responsible for giving approval.

Tenth, if the environmental management and monitoring plan is declared imperfect by the minister or governor based on the commission's evaluation, the initiator is given 30 days to revise it. If the deadline of 30 days is passes, the environmental management and monitoring plan is assumed to be approved. In this period, the decision of approval on the environmental impact assessment is a decision that greatly determines whether an activity can be executed. However, if there is no activity carried out by the initiator within 5 (five) years since the issuance of the approval on the environmental impact assessment, the decision is considered expired. Therefore, the initiator should submit a new proposal.

The minister or governor can grant re-approval based on new environmental impact assessment, environmental management and monitoring plan, or previous documents that can still be used. In addition to expiration, the decision of approval for the environmental impact assessment can be declared void. Such approval is void if there is a fundamental environmental change due to natural events or other events before the activity is carried out. If this happens, the initiator must make a new environmental impact assessment based on a new environmental zone based on the prevailing regulation. If the previous location has obtain approval for the environmental impact assessment and undergone fundamental environment change, the initiator does not have to make a new environmental information and the location undergoing fundamental changes can be used as the basis to make a new environmental impact assessment. 


\subsubsection{Period 1993-1997}

The process and guideline of making the environmental impact assessment in this period were regulated in Government Regulation Number 51 of 1993 on environmental impact assessment as an improvement for Government Regulation Number 29 of 1986 as mandated in Law Number 4 of 1982 concerning Basic Provisions of Environmental Management Article (16). The process of making the environmental impact assessment starts with determining the type of business or activity estimated to have significant impacts on the environment. This is determined by the minister assigned to manage environment and control environmental impacts, after considering advices and opinions from the minister or person in charge of a non-department government institution.

If the business or activity plan has been determined to make the environmental impact assessment, according to this Government regulation the stages carried out in the process of environmental impact assessment are as follows.

First, the initiator must make a term of reference for the making of environmental impact assessment. The term of reference is submitted to the commission of environmental impact assessment to obtain written correction or feedback within 12 days. If the deadline is passes, the term of reference is declared valid as the basis for making the environmental impact assessment.

Second, after the term of reference is approved by the commission of environmental impact assessment, the initiator starts making environmental impact assessment, environmental management and monitoring plan, and submitting to the responsible institution, in this case the minister or the governor. After it is evaluated by the commission of environmental impact assessment (within 45 days after the document is accepted, the commission of environmental impact assessment must have assessed and made a decision on the acceptance or rejection of the document). If within the time given the commission has not made a decision, the document is declared valid and approved.

Third, if the environmental impact assessment, environmental management and monitoring plan is rejected, the initiator is given 30 days to make a revision. If within the time given the commission of environmental impact assessment has not made a decision, the document is declared approved to be accepted based on the power of the regulation.

Fourth, if the document of environmental impact assessment concludes that negative impacts of the activity cannot be overcome based on science and technology and the cost to overcome such impact is larger than the positive impact, the minister or governor should decide to reject. In regard to this decision, the initiator is given 14 days to file an objection to the rejection. 
Subsequently, the responsible institution in this case the minister in charge of business and/or activity coordinates with the minister assigned to manage environmental impacts to make a decision at the latest 30 days since the initiator files an objection to the rejection of the activity. According this Government Regulation, this decision in the procedures of environmental impact assessment process in Indonesia is a final decision.

Fifth, the approval for environmental impact analysis, environmental management and monitoring plan is declared expired if the activity is not executed for 3 (three) years after the decision is issued. If it is declared expired, the initiator can submit an approval request to the responsible institution (Minister in charge of the activity or Governor). The institution decides whether the previous document can be re-used or must be renewed.

Sixth, the approval decision is declared void if there is a fundamental environmental change due natural events or other events before and during the time in which activity is executed. Afterwards, the environmental condition that has undergone fundamental changes can be reused as a new picture of environmental setting that will be reused as the basis for making environmental impact assessment, environmental management and monitoring plan documents. The most fundamental difference of the government regulations between the previous period and this period is that the EIP is not made as the basis for determining the making of environmental impact assessment, environmental management and monitoring plan documents. In addition, the duration for the process of environmental impact assessment is different. This government regulation only takes a maximum of 131 days, while the previous government regulation could take a maximum of 224 days.

\subsubsection{Period 1998-2008}

The period 1998 to 2008 is reform transition period until reform period. In this period, laws and regulations underwent changes as the result of the changes in government. Government Regulation concerning environmental impact analysis referred to Law Number 23 of 1997 serving as a substitute of Law Number 4 of 1982. This Law had been adjusted from the previous Law. Such adjustment included the word "lingkungan" (environment) which was no longer used, but changed into "lingkungan hidup" (living environment). This change gave a profound meaning, that a living environment was a condition in which human behaviors was the main focus in studying the change in the quality of environment. In addition, the sustainable development had clearly become the first consideration in making this Law.

In this period, the prevailing regulation concerning environmental impact analysis was Government Regulation Number 27 of 1999. In this regulation, there is a difference from the previous government regulation, namely the 
phrase "Dampak besar dan penting" (Major and significant impact), previously only "Dampak penting" (Significant impact) in order to indicate fundamental environmental changes caused by an activity. The processes taking place in this Government Regulation are maximum 150 days. Stages in the making of environmental impact assessment are as follows.

First, the term of reference is made by the initiator and submitted to the responsible institution (Head of Institution assigned to control environmental impacts at the Central level or governor at regional level) through the central or regional audit commission.

Second, the decision on evaluation results on the term of reference takes a maximum of 75 days, and if within such period of time the audit commission does not make a decision, the term of reference is declared valid. One important thing is that is the term of reference must be rejected if the activity plan is not in accordance with the regional spatial planning.

Third, after the term of reference is accepted, the initiator makes environmental impact assessment, environmental management and monitoring plan based on the term of reference. Subsequently, the initiator submits the documents of environmental impact assessment, the environmental management plan and environmental monitoring plan to the audit commission to be evaluated and decided its environmental feasibility (at the latest 75 days).

Fourth, the decision of environmental feasibility issued by the responsible institution must be attached with suggestions, opinions, and responses submitted by the people.

Fifth, the decision on environmental unfeasibility is issued by the audit commission if major and significant negative impact caused by the business and/or activity cannot be overcome by the available technology and if the cost to overcome is greater than the benefits. If the decision of unfeasibility is issued by the responsible institution, the responsible institution must reject the business license proposed by the initiator.

Sixth, the decision of environmental feasibility issued by the responsible institution is declared expired if the activity is not executed within 3 years after the issuance of the decision of environmental feasibility. In this case, the initiator is required to resubmit the approval request for the environmental impact assessment, environmental management plan and environmental monitoring plan to the responsible institution. Subsequently, the responsible institution can have the initiator to make a new document or to reuse the old documents fully.

Seventh, the decision of environmental feasibility is declared void if the initiator moves the location of business and/or activity, changes design, process, capacity, raw materials, supporting materials or there is fundamental environmental changes due to natural events and other events before and during the time in which the business and/or activity is executed. 


\subsubsection{Period 2009-present}

Government regulation concerning environmental impact assessment in the period 2009 until the present time was based on Law Number 32 of 2009 conservation the environment conservation and management. In this law, it is stated in Article (14) that one of the instruments to prevent environmental damage and pollution is environmental impact assessment, and because environmental impact assessment is one of the instruments in granting environmental license, Article (41) mandates to regulate environmental license in the form of Government Regulation.

The aforementioned government regulation is Government Regulation Number 27 of 2012 concerning Environmental License. In this period, the decision on the environmental feasibility that is obtained through the following process of environmental impact assessment.

First, a business and/or activity plan estimated to have significant impacts on environmental components is required to have an environmental impact assessment. The provisions for the type of business and/or activity that is required to have an environmental impact assessment has been stipulated in the Regulation of Minister of Environment Number 05 of 2012, while the procedure for evaluation and license issue is regulated in the Regulation of Minister of Environment Number 08 of 2013 on Procedures for Evaluation and Examination of Environmental Documents as well as Issuance of Environmental License.

Second, the initiator submits a term of reference to the Audit Commission of Environmental Impact Assessment to be technically examined and audited in order to obtain an approval from the commission. The period for evaluating the term of reference until the issuance of letter of approval is a the latest 30 working days after it is declared complete administratively.

Third, after obtaining approval for the term of reference, the initiator submits the environmental impact assessment, environmental management plan and environmental monitoring plan to be evaluated by the Audit Commission of Environmental Impact Assessment to obtain the recommendation for environment feasibility or unfeasibility. The maximum period for evaluating until obtaining the recommendation is at the latest 75 working days.

Fourth, based on the recommendation from the Audit Commission of Environmental Impact Assessment, the initiator will obtain a letter of decision on the environmental feasibility and environmental license from the Minister, Governor or Regent/Mayor in accordance with their respective authority.

\section{CONCLUSION}

The history of environmental impact assessment in Indonesia began when Indonesia participated in the Conference on the Human Environment (UNCHE) 
in Stockholm in 1972. In 1973, the Government of Republic of Indonesia issued an environmental development program as stipulated in the Decree of the People's Consultative Assembly Number IV of 1973 in the Broad Outlines of State Policy Chapter III Part B item (10). This became the origin of the birth of Environmental Law Number 4 of 1982 as the first law in Indonesia regulating the Basic Provisions of Environmental Management. The environmental law has changed twice until the present time, namely Law Number 23 of 1997 on Environmental Management and Law Number 32 of 2009 on Environmental Conservation and Management. The changes in Laws were followed by the changes in government regulations concerning environmental impact assessment. Government Regulation Number 29 of 1986 was replaced with Government Regulation Number 51 of 1993, then Government Regulation Number 27 of 1999 and current Government Regulation Number 27 of 2012 on Environmental License.

\section{References}

Canter LW. 1996. Environmental impact assessment. Second edition. Inc. Mc Graw-Hill. New York.

Death C. 2014. Mengelola pembangunan yang berkelanjutan (kemitraan, protes, dan kekuasaan Di KTT dunia). Pustaka Pelajar. Yogyakarta.

Decree of Head of Environmental Impact Management Agency Number 08 of 2000 on Community Involvement and information disclosure in the process of environmental impact assessment.

Hadi SP. 2009. Aspek sosial AMDAL sejarah, teori dan metode. Gadjah Mada University Press. Yogyakarta.

Government Regulation No. 29 of 1986 on Environmental Impact Assessment. Government Regulation No. 51 of 1993 on Environmental Impact Assessment. Government Regulation No. 27 of 1999 on Environmental Impact Assessment. Government Regulation No. 27 of 2012 on Environmental License.

Law No. 4 of 1982 on Basic Provisions for Environmental Management.

Law No. 23 of 1997 on Environmental Management.

Law No. 32 of 2009 on Environmental Conservation and Management.

Regulation of Minister of Environment No. 16 of 2012 on Guidelines for the Making of Environmental Documents.

Regulation of Minister of Environment No. 17 of 2012 concerning Guidelines for Community Involvement in the Process of Environmental Impact Assessment and Environmental License.

Regulation of Minister of Environment Number 5 of 2012 concerning Types of Business and/or Activity Plans that Must Have Environmental Impact Assessment. 
Regulation of Minister of Environment Number 08 of 2013 concerning Procedures of Evaluation and Audit of Environmental Documents and Issuance of Environmental License.

Zamorano. 2013. A qualitative method proposal to improve environmental impact assessment. environmental impact assessment review 43:9-20. 